\author{
Domenico Francavilla \\ (professore ordinario di Diritto privato comparato \\ nell’Università degli Studi di Torino, Dipartimento di Giurisprudenza)
}

\title{
La complessità dei diritti personali e il dibattito sul Codice civile uniforme in India *
}

The complexity of personal laws and the debate on the Uniform Civil Code in India

\begin{abstract}
The promulgation of the Uniform Civil Code, envisaged in the Indian Constitution as a Directive Principle of State Policy, has been at the center of a debate on overcoming the application of personal laws in matters of family and succession that has always been present in the Indian context and has recently been revived. The contribution identifies as useful keys for analysis on the one hand the logic of uniformisation as choice and, on the other hand, complexity, understood both as the operational difficulty of managing a system of laws applied on a personal basis and as a basic feature of continuous interactions between different principles and rules in a highly pluralistic context.
\end{abstract}

SOMMARIO: 1. Introduzione - 2. La logica dell'uniformazione - 3. Due significati di "complessità".

\section{1 - Introduzione}

Il Codice civile uniforme (Uniform Civil Code), previsto nell'art. 44 della Costituzione indiana nella parte IV sui Directive Principles of State Policy ${ }^{1}$, è

* Contributo non sottoposto a valutazione.

L'Autore ringrazia Roberto Toniatti in particolare per la possibilità di presentare e discutere alcune delle idee analizzate in questo contributo con la relazione "The complexity of personal laws in India", presentata all'International Workshop The Debate on the Uniform Civil Code in India: New Perspectives on Constitutional Secularism in India and Personal Laws Regimes in Asia?, Università di Trento, Facoltà di Giurisprudenza (27-28 aprile 2017). Una versione precedente di questo contributo è disponibile nel Blog per $i 70$ anni di Roberto Toniatti - Pluralismo nel diritto costituzionale comparato (2020), a cura di J. WOELK, C. CASONATO, L. ANTONIOLLI e M. DANI.

${ }^{1}$ L'art. 44 (Uniform civil code for the citizens) stabilisce che: "The State shall endeavour to secure for the citizens a uniform civil code throughout the territory of India". L'uniformità nel dibattito qui analizzato si riferisce alle materie del diritto di famiglia $\mathrm{e}$ delle successioni, considerato che altre parti del diritto civile sono già applicati su base 
stato dall'inizio della storia dell'India indipendente un punto centrale per comprendere le tendenze evolutive del diritto indiano, in particolare, naturalmente, per quel che riguarda il futuro dei diritti personali, vale a dire di diritti differenziati sulla base dell'appartenenza religiosa e comunitaria in materia di famiglia e successioni e in alcune questioni minori, e più in generale per quel che riguarda il rapporto tra diritto e politica, il rapporto tra maggioranza hindu e minoranze religiose, e la messa in opera della Costituzione, a settant'anni dalla sua entrata in vigore.

Anche oltre l'India, questa questione ha grande importanza e ha sollecitato l'attenzione degli studiosi. Infatti, sul piano teorico l'applicazione dei diritti personali nel contesto indiano rappresenta un caso "gigante" di pluralismo giuridico in azione in una grande democrazia. Quel che accade in India sotto questo profilo è quindi sicuramente importante sia per comprendere l'evoluzione giuridica, e assieme sociale e politica, indiana, sia per comprendere meglio le dinamiche del pluralismo giuridico su scala globale.

La vicenda del Codice civile uniforme è inoltre molto interessante sul piano tecnico-giuridico, come ogni nuovo progetto di codice può essere. Un nuovo codice civile promulgato in India nei prossimi anni, per quanto in un ambito di materie limitato, rappresenterebbe una nuova iterazione dell'idea di codice che ha assunto tanta importanza nella storia del diritto. Infine, non bisogna dimenticare l'impatto sociale di questo nuovo codice. Il progetto di uniformazione del codice è infatti collegato al bisogno di riforma della disciplina di diversi istituti sia per quel che riguarda il diritto islamico che quello hindu.

Il dibattito è ripreso con grande intensità negli ultimi anni. Particolarmente significativo sotto questo aspetto è stato il caso Shayara Bano $^{2}$, così come la promozione da parte della Law Commission of India di una raccolta di opinioni in risposta a un questionario sui diritti personali e la pubblicazione di un paper sulle riforme del diritto di

territoriale e non personale e la diversità può derivare dal normale gioco delle materie concorrenti tra diritto dell'Unione e diritto degli Stati

2 Shayara Bano v. Union of India and Ors., Supreme Court of India, 2017. Per un'analisi di questa importante sentenza si vedano C. CORRENDO, La Corte Suprema indiana tra istanze religiose, conflitti intercomunitari e questioni di genere, in DPCE Online, 33, 4, 2018, pp. 1007-1012, e D. SCOLART, Diritto personale v. diritto statale: riflessioni a partire dalla sentenza della Corte Suprema indiana del 22 agosto 2017 sul triplice ripudio, in Diritto, immigrazione e cittadinanza, 3, 2017, pp. 1-15. 
famiglia ${ }^{3}$. In definitiva, la Law Commission (la ventunesima) ha ritenuto che non ci sia sufficiente consenso per il Codice civile uniforme, ma è in fase di formazione la 22nd Law Commission e potrebbe quindi esservi in futuro un cambio di atteggiamento. Per stimolare la preparazione di un codice civile uniforme, sono state anche presentate Public Interest Litigation dinanzi alla Delhi High Court, e si è tentato di introdurre in Parlamento un Uniform Civil Code Bill in forma di private bill, nel 2019 e nel 2020.

Il tema è uno dei più complessi del diritto indiano ${ }^{4}$. In questo contributo considererò solo alcuni aspetti del dibattito approfondendo in particolare due aspetti, a mio avviso cruciali per comprendere la situazione attuale e per immaginare gli sviluppi futuri, vale a dire quello della logica generale dei processi di uniformazione giuridica e quello della complessità dell'applicazione dei diritti personali nel contesto indiano.

\section{2 - La logica dell'uniformazione}

Una prima osservazione è che la tensione tra uniformità e diversità è un problema globale che sembra essere essenziale alla dinamica stessa del diritto, tanto che l'intera storia del diritto potrebbe essere considerata in questa prospettiva. L'idea stessa di codice ha tra i suoi valori centrali quello dell'uniformità, sia storicamente sia nei progetti più recenti. Anche se il dibattito sull'uniformità in India è condotto con riferimento al codice, bisogna però ricordare che l'uniformità non implica necessariamente un codice, visto che può essere raggiunta, progressivamente, oltre che attraverso una serie di leggi mirate, anche attraverso il ruolo svolto dalla giurisprudenza nell'interpretazione delle norme esistenti e dalla dottrina. Sinora, pur in assenza di codice, i diritti personali hanno assunto una traiettoria di uniformazione proprio grazie all'opera delle Corti, che

${ }^{3}$ LAW COMMISSION OF INDIA, Consultation Paper on Reform of Family Law (31 August 2018).

${ }^{4}$ La bibliografia sul tema è molto ampia. Si vedano in particolare W. MENSKI, The Uniform Civil Code debate in Indian law: New developments and changing agenda, in German Law Journal, 9 (3), 2008, pp. 211-250, W. MENSKI, Hindu Law: Beyond Tradition and Modernity, Oxford University Press, Oxford, 2003, e F. AGNES, Personal Laws, in The Oxford Handbook of the Indian Constitution, a cura di S. CHOUDHRY, M. KHOSLA e P.B. MEHTA, Oxford University Press, Oxford, 2016. Si veda anche T. HERKLOTZ, Law, religion and gender equality: literature on the Indian personal law system from a women's rights perspective, in Indian Law Review, 1, 3, 2017, pp. 250-268. 
interpretano i diritti personali nel quadro costituzionale ${ }^{5}$. Un processo d'uniformazione è quindi già in corso.

Una seconda osservazione riguarda le difficoltà interne del pluralismo giuridico. Qualsiasi sistema giuridico si decida di analizzare, si può osservare un fenomeno che possiamo definire di replica del pluralismo. La pluralità di componenti del sistema giuridico che osserviamo a un certo livello, con la coesistenza e interazione di diverse parti, si può riprodurre al livello delle singole parti. Ad esempio, se nell'ambito dei diritti personali indiani abbiamo un primo livello di pluralità in cui possiamo riconoscere diritto hindu, diritto islamico, diritti cristiani, diritto ebraico, diritto parsi, ognuno di questi diritti ha una sua ulteriore pluralità interna, che si può replicare a sua volta scomponendosi sempre di più.

Se accettiamo questa prospettiva, possiamo trovarci nel dilemma dei limiti del pluralismo. In altri termini, se accettiamo il valore della diversità nel diritto, del riconoscimento ampio di diversi sistemi di regole, che inglobano almeno in parte diversi valori e concezioni del mondo, non è facile collocare una linea che definisca il livello appropriato di riconoscimento/limitazione di questa pluralità. Visto che la pluralità si replica a più livelli, si può arrivare al caso limite di un sistema giuridico per ogni individuo, ma arrivati a questo punto la stessa natura del diritto, almeno per come siamo abituati a pensarlo, va in crisi. Naturalmente qui la prospettiva è principalmente quello dello Stato che intenda razionalizzare il pluralismo e il problema può non porsi da altri punti di vista.

Anche in comunità molto coerenti culturalmente, in cui si condividono gli stessi valori, possiamo trovare diverse soluzioni giuridiche e possiamo soprattutto trovare diversi livelli di adesione alle stesse regole. In altri termini, nel funzionamento del diritto c'è un livello in cui non tutte le visioni, non tutte le idee su cosa è appropriato possono essere riconosciute. Il discorso può inoltre essere spostato su un altro piano e ci si può chiedere quali siano i limiti del diritto come mezzo per garantire l'ordine sociale. Infatti, non tutte le interazioni sono regolate dal diritto e si potrebbe anche sostenere che in realtà l'uniformità del diritto non tocchi radicalmente la pluralità e il riconoscimento della diversità complessiva in una società, che può essere preservata indipendentemente dal diritto ${ }^{6}$.

\footnotetext{
${ }^{5} \mathrm{Si}$ veda W. MENSKI, The Uniform Civil Code debate in Indian law, cit.

${ }^{6} \mathrm{Si}$ veda D. FRANCAVILLA, The Uniformisation of Family Law in Europe and the Place of
} 
La logica dell'uniformazione si può individuare in un processo di selezione. L'uniformazione è il risultato di una scelta tra diverse regole che legittimamente rivendicano di essere le regole appropriate. Tra queste se ne potrà affermare una, e in contesti pluralistici più di una, sulla base di una differenziazione "ragionevole". Allora il problema dell'uniformazione è quali di queste regole debbano essere adottate e generalizzate all'intera comunità e, quindi, almeno in parte imposte su gruppi che sono portatori di un diverso sistema di regole. Questo processo, che va dalla diversità all'uniformità, non è lineare e vi è un concorrente processo dall'uniformità alla diversità, perché nuove interpretazioni, nuove regole, nuove prospettive, continuamente sorgono, rialimentando diversità. Rimane un bisogno antropologico di selezionare alcune regole di comportamento, di istituzionalizzarle e di porle in un circuito di trasmissione e di diffusione ad altre generazioni e ad altre parti delle società.

Come è noto, il dibattito sul Codice civile uniforme in India viene principalmente inquadrato nei termini della divisione tra comunità hindu e comunità musulmana. Il Codice civile uniforme indiano è stato spesso considerato e rappresentato come un codice in contrapposizione alla specificità giuridica della comunità musulmana indiana, anche se il discorso pubblico lo presenta soprattutto negli ultimi tempi come uno strumento riformista che tocca in pari modo tutti i diritti personali che vuole superare, cercando di far prevalere le considerazioni di giustizia sociale, e in particolare di miglioramento della condizione delle donne, rispetto a quelle relative al rapporto tra comunità religiose indiane.

Non è quindi solo questione di poligamia e ripudio islamici, ma anche, ad esempio, di diritti di successione delle donne hindu. Detto questo, e lasciando sullo sfondo le forti implicazioni politiche, il Codice civile uniforme tenderebbe ad avere un impatto maggiore sulla comunità musulmana, se non altro perché, con riferimento al diritto personale hindu, c'è stato già, in particolare nei primi anni successivi alla entrata in vigore della Costituzione, un intervento legislativo importante, mentre sul diritto islamico non si è intervenuti legislativamente in modo esteso e organico ${ }^{7}$.

Ethnic Minorities, in Family, Religion and Law: Cultural Encounters in Europe, a cura di P. SHAH, M.-C. FOBLETS e M. ROHE, Ashgate, Farnham, 2014, pp. 103-114.

7 Per una introduzione alle fonti dei diversi diritti personali in India si veda C. CORRENDO, D. FRANCAVILLA, Legislazione e diritti personali in India, in Quaderni di Diritto e Politica Ecclesiastica, 2, 2017, pp. 357-375. 
La giurisprudenza indiana, pur avendo avuto un ruolo chiave nell'applicazione ed evoluzione dei diritti personali, ha più volte richiamato il legislatore alla messa in opera dell'art. 44 delle Costituzione. Probabilmente la citazione più famosa sotto questo profilo è quella che si trova nel caso Shah Bano, quando si legge:

\begin{abstract}
"A common Civil Code will help the cause of national integration by removing disparate loyalties to laws, which have conflicting ideologies. It is the State which is charged with the duty of securing a uniform civil code for the citizens of the country and, unquestionably, it has the legislative competence to do so. A beginning has to be made if the Constitution is to have any meaning. Inevitably, the role of the reformer has to be assumed by the courts because it beyond the endurance of sensitive minds to allow injustice to be suffered when it is so palpable. But piecemeal attempts of courts to bridge the gap between personal laws cannot take the place of a common Civil Code" 8 .
\end{abstract}

Il giudiziario nel suo complesso sostiene il progetto del codice civile uniforme. Bisogna però distinguere due aspetti. Il primo è che per i giudici, che si sentono parte del processo di trasformazione concepito dall'Assemblea costituente, il fatto che l'art. 44 rimanga inattuato costituisce un problema. Al di là di questa affermazione spesso fatta dai giudici, è difficile comprendere se e in quale misura gli stessi giudici si siano abituati a "navigare" attraverso questo sistema di diritti personali e si sia diffusa una percezione del suo adeguato funzionamento e quanto invece il codice sia ritenuto necessario alla stessa pratica quotidiana del diritto.

Sicuramente alcune scelte difficili in materia di diritti personali, secondo i giudici, dovrebbero essere compiute dal legislativo. Ma per quel che riguarda la legislazione a lungo la questione non è stata toccata perché troppo complessa. Nella società, l'impressione è che i problemi percepiti si collochino spesso al livello delle ingiustizie concrete e il Codice civile uniforme può essere attraente nella misura in cui riesce a essere presentato come uno strumento utile per superare queste ingiustizie. Certamente però il discorso è politicizzato e a livello sociale emergono movimenti d'opinione che supportano o contrastano questo codice, da diversi punti di vista, in quanto passo decisivo verso il superamento dei diritti religiosi nel contesto indiano.

${ }^{8}$ Mohd. Ahmed Khan v. Shan Bano Begum, Supreme Court of India, 1985. Per un'analisi si veda W. MENSKI, The Uniform Civil Code debate in Indian law, cit. 
Rimane quindi non del tutto chiaro se il progetto di superamento dei diritti personali si basi su una critica di questo tipo di organizzazione istituzionale della complessità interna del sistema giuridico o su una critica dei singoli diritti personali; se, in altri termini, il problema sia la mancanza di uniformità, o se siano aspetti specifici del diritto hindu, del diritto islamico o di altri diritti ufficialmente vigenti in India. In ogni caso, ci si può chiedere se i due discorsi siano realmente separabili ed è diffusa la posizione per cui un sistema di diritti personali non può che essere in conflitto con i valori costituzionali e in particolare con l'uguaglianza.

$\mathrm{Ci}$ sono quindi molte visioni, spesso polarizzate, sul funzionamento del sistema di diritti personali e sul valore e sulla fattibilità di un Codice civile uniforme. Sino a non molti anni fa il dibattito sull'art 44 era presente ma meno attuale perché non era nelle priorità degli schieramenti politici al governo. Bisogna sottolineare che l'art. 44 prevede un endeavour, un adoperarsi al fine della promulgazione del Codice civile uniforme, senza vincolare temporalmente il risultato. Questo dovere costituzionale di endeavour non è comunque lettera morta; si tratta di un obiettivo costituzionale che disegna una traiettoria. Molto dipende dalla più o meno estesa percezione della necessità o meno di un Codice civile uniforme come strumento da utilizzare per raggiungere, attraverso l'uniformazione e gli altri valori, in primo luogo quello della certezza, insiti nell'idea di codice, un quadro giuridico di maggiore tutela dei diritti fondamentali e in generale delle posizioni soggettive, che permetta anche alle corti di svolgere meglio il proprio ruolo nel rendere effettivamente giustizia nella società indiana.

Se si può utilizzare il termine "polarizzazione" per evidenziare gli antagonismi e le contrapposizioni che caratterizzano il dibattito, occorre anche evidenziare che il fatto che dopo settanta anni dalla Costituzione non ci sia ancora questo codice si può spiegare in parte con un atteggiamento che ha profonde radici nella cultura giuridica indiana e può essere caratterizzato come ricerca di una sintesi tra posizioni divergenti accettandole entrambe e collocandole in ordine gerarchico. In altri termini, l'Assemblea costituente era a favore del Codice civile uniforme ma accettava il sistema dei diritti personali. I giudici sono largamente a favore del Codice civile uniforme ma si muovono all'interno del sistema dei diritti personali. In questo approccio gerarchico si può quindi riconoscere un valore e una legittimità al sistema dei diritti personali, pur mantenendo il senso di una direzione verso la realizzazione del progetto previsto nell'art. 44 della Costituzione. Da questo punto di vista, si può ritenere che nella cultura giuridica indiana attuale sia presente una modalità di pensiero giuridico molto evidente nella cultura giuridica classica, e del 
resto non solo indiana, per cui più soluzioni possono essere parimenti valide e, tra queste, una può considerarsi preferibile, piuttosto che l'unica corretta.

\section{3 - Due significati di "complessità"}

Il termine "complessità" nel titolo di questo contributo può avere più significati. Senz'altro uno connotato positivamente, nella misura in cui veicola l'idea di una creatività, della possibile emersione di novità nel campo del diritto grazie all'interazione di molte componenti, e molto diverse tra di loro. Questo aspetto è rilevante nell'applicazione dei diritti personali in India, che evolve in modo originale alla ricerca costante di un equilibrio tra le sue varie parti. Il termine "complessità" può avere però anche una connotazione negativa, facendo riferimento alle complicazioni e difficoltà che sorgono nella "gestione" di un sistema di diritti personali.

Entriamo maggiormente nell'analisi di questa complessità. La prima cosa da ricordare è che essa proviene dal passato. L'Assemblea costituente, nel preparare il testo fondamentale della Repubblica indiana, dovette compiere molte scelte sul diritto applicabile, non solo per quel che riguarda i diritti personali. Non tutto poteva essere riformato immediatamente a rischio di porre in crisi il normale funzionamento della giustizia. Un articolo importante a questo proposito è l'art. 372 (Continuance in force of existing laws and their adaptation), secondo il quale:

"(1) Notwithstanding the repeal by this Constitution of the enactments referred to in article 395 but subject to the other provisions of this Constitution, all the law in force in the territory of India immediately before the commencement of this Constitution shall continue in force therein until altered or repealed or amended by a competent Legislature or other competent authority".

L'espressione "law in force" è stata intesa in senso ampio, includendo statutory law ma anche diritto hindu e islamico per come erano applicati prima dell'entrata in vigore della Costituzione9. Questo diritto "passa" dal periodo coloniale al periodo dell'India indipendente. Esiste però un filtro immediato, l'art. 13 nella Parte III della Costituzione sui diritti fondamentali, in base al quale:

9 Si veda M.P. JAIN, Indian Constitutional Law, Eight edition, LexisNexis, Gurgaon, 2018, p. 1627. 
"(1) All laws in force in the territory of India immediately before the commencement of this Constitution, in so far as they are inconsistent with the provisions of this Part, shall, to the extent of such inconsistency, be void"10.

Non essendo stato ritenuto possibile promulgare subito un Codice Civile Uniforme, si è intervenuti in prima battuta sul diritto personale della maggioranza hindu, con quattro leggi: Hindu Marriage Act, 1955; Hindu Minority and Guardianship Act, 1956; Hindu Adoption and Maintenance Act, 1956; Hindu Succession Act, 1956. Lo spirito complessivo di queste quattro leggi è stato quello di semplificare, codificare e riformare il diritto hindu. Ci sono stati successivamente importanti emendamenti, e, affianco a queste leggi che intervengono sui diritti personali, ci sono state leggi di carattere territoriale, che si applicano a tutti i cittadini indiani indipendentemente dall'appartenenza religiosa, anche in materie rientranti nei diritti personali, ad esempio The Prohibition of Child Marriage Act, 2006, che è anche un esempio della tendenza verso l'uniformità per via legislativa, in assenza di codice. Ugualmente bisogna ricordare lo Special Marriage Act, 1954 destinato a regolare principalmente i matrimoni interreligiosi, ma "aperto" a essere applicato opzionalmente a tutti, e quindi considerato nucleo centrale di un diritto uniforme facoltativo.

Per il diritto islamico, gli interventi legislativi sono stati molto minori. È rimasto in vigore il Muslim Personal Law (Shariat) Application Act, del 1937 e quindi precedente l'Indipendenza e la Costituzione. Si tratta di una legge molto breve che all'art. 2 dispone:

"Notwithstanding any custom or usage to the contrary, in all
questions (save questions relating to agricultural land) regarding
intestate succession, special property of females, including personal
property inherited or obtained under contract or gift or any other
provision of Personal Law, marriage, dissolution of marriage,
including talaq, ila, zihar, lian, khula and mubaraat, maintenance,
dower, guardianship, gifts, trusts and trust properties, and wakfs
(other than charities and charitable institutions and charitable and
religious endowments) the rule of decision in cases where the parties
are Muslims shall be the Muslim Personal Law (Shariat)".

Bisogna inoltre ricordare che, per quel che riguarda le competenze di Unione e singoli Stati, il diritto di famiglia e quello delle successioni rientrano nell'elenco delle materie concorrenti. Per quanto non molto

10 Dibattuta è l'inclusione di "personal laws" nel significato del termine "laws" ai sensi dell'art. 13 e quindi la possibilità di judicial review. Su questo punto si veda F. AGNES, Personal Laws, in The Oxford Handbook of the Indian Constitution, cit. 
rilevante sul piano quantitativo, abbiamo quindi un ulteriore elemento di diversità, riconducibile però in questo caso al normale funzionamento di uno Stato federale.

Il punto più significativo da mettere in evidenza è quello del grado di uniformità negli stessi diritti personali singolarmente considerati. Se consideriamo la sezione 2 dell'Hindu Marriage Act, osserviamo in effetti una tendenza verso l'uniformazione e la semplificazione. La legge si applica agli hindu per religione e, nella formulazione della norma, appare una chiara consapevolezza dal punto di vista legislativo della pluralità interna dell'induismo, ma si applica anche a sikh, buddhisti e jainisti, che non sono hindu per religione ${ }^{11}$. Inoltre, espressamente non si applica a musulmani, cristiani, ebrei e parsi ma può applicarsi a tutti coloro per i quali non si provi che non sarebbero stati governati dal diritto hindu in queste materie prima dell'entrata in vigore dello stesso Hindu Marriage Act.

Come si fa a definire l'appartenenza all'induismo e alle altre comunità a cui la legge deve applicarsi? Su questo la stessa sezione 2 contiene una explanation, che fornisce alcune indicazioni al giudice ${ }^{12}$. Si noti che le questioni dell'appartenenza religiosa sono molto complesse anche perché i criteri statali e quelli interni alle religioni possono divergere. La questione è tanto affascinante dal punto di vista della scienza delle religioni quanto difficile da risolvere per un giudice statale, tenendo anche presente che da questa decisione dipende l'intero regime

11 In base alla Sec. 2 (Application of Act): "(1) This Act applies- (a) to any person who is a Hindu by religion in any of its forms or developments, including a Virashaiva, a Lingayat or a follower of the Brahmo, Prarthana or Arya Samaj, (b) to any person who is a Buddhist, Jaina or Sikh by religion, and (c) to any other person domiciled in the territories to which this Act extends who is not a Muslim, Christian, Parsi or Jew by religion, unless it is proved that any such person would not have been governed by the Hindu law or by any custom or usage as part of that law in respect of any of the matters dealt with herein if this Act had not been passed".

12 L'explanation chiarisce che: "The following persons are Hindus, Buddhists, Jainas or Sikhs by religion, as the case may be,- (a) any child, legitimate or illegitimate, both of whose parents are Hindus, Buddhists, Jainas or Sikhs by religion; (b) any child, legitimate or illegitimate, one of whose parents is a Hindu, Buddhist Jaina or Sikh by religion and who is brought up as a member of tribe, community, group or family to which such parents belongs or belonged; and (c) any person who is a convert or re-convert to the Hindus, Buddhist, Jaina or Sikh religion". 
applicabile. In un sistema di diritti personali altre questioni complesse derivano dalle conseguenze giuridiche delle conversioni ${ }^{13}$.

In termini generali la logica degli Hindu acts era quella di semplificare il diritto hindu e da questo punto di vista è interessante la sezione 4 (Overriding effect of Act), per cui:

\begin{abstract}
"Save as otherwise expressly provided in this Act, - (a) any text rule or interpretation of Hindu law or any custom or usage as part of that law in force immediately before the commencement of this Act shall cease to have effect with respect to any matter for which provision is made in this Act; (b) any other law in force immediately before the commencement of this Act shall cease to have effect in so far as it is inconsistent with any of the provisions contained in this Act".
\end{abstract}

La disciplina legislativa intende quindi superare le regole preesistenti.

$\mathrm{Ma}$ in che modo si raggiunge uniformità? Come dicevamo in precedenza, per quel che riguarda il diritto hindu, l'uniformità può essere raggiunta generalizzando le regole di una parte della società hindu a tutti gli hindu. Questo è stato il caso della poligamia, da sempre presente in alcune parti dell'induismo, che l'Hindu Marriage Act non riconosce - il secondo matrimonio è nullo e la bigamia è reato ${ }^{14}$. La regola naturalmente ha un impatto diverso a seconda che si tratti di comunità che già prima dell' Hindu Marriage Act seguivano la monogamia o di comunità che praticavano la poligamia. In altri termini, per alcuni hindu questo intervento non fa differenza perché già seguivano la regola che il legislativo ha scelto come migliore. Mentre per altre comunità la differenza sarà cruciale.

Altro aspetto da evidenziare è che, nel perseguire l'uniformazione, l'Hindu Marriage Act conserva spazi di diversità con il riconoscimento esplicito del valore delle consuetudini in diversi casi. L'esempio più importante è probabilmente quello della sezione 7 sulla celebrazione dei matrimoni ${ }^{15}$. Abbiamo qui un rinvio completo alle consuetudini di almeno

\footnotetext{
${ }^{13}$ Si vedano sul punto Lily Thomas v. Union of India, Supreme Court of India, 2000, e il rapporto della LAW COMMISSION OF INDIA, Preventing Bigamy via Conversion to Islam - A Proposal for giving Statutory Effect to Supreme Court Rulings, Report n. 227 (2009).

14 Si veda W. MENSKI, Hindu Law, cit.

15 In base alla Sec. 7 (Ceremonies for a Hindu marriage): “(1) A Hindu marriage may be solemnized in accordance with the customary rites and ceremonies of either party thereto. (2) Where such rites and ceremonies include the Saptapadi (that is, the taking of seven steps by the bridegroom and the bride jointly before the sacred fire), the marriage becomes complete and binding when the seventh step is taken".
} 
una delle parti, in una questione cruciale perché investe la stessa esistenza di un matrimonio.

Sul piano generale, $1^{\prime} H i n d u$ Marriage Act si preoccupa di definire i caratteri che una consuetudine deve avere per poter essere applicata dal giudice statale. La sezione 3 (Definitions) stabilisce che:

"In this Act, unless the context otherwise requires, - (a). the expressions "custom" and "usage" signify any rule which, having been continuously and uniformly observed for a long time, has obtained the force of law among Hindus in any local area, tribe, community, group or family: Provided that the rule is certain and not unreasonable or opposed to public policy; and Provided further that in the case of a rule applicable only to a family it has not been discontinued by the family".

Questa norma conduce i giudici a doversi esercitare su complesse questioni relative all'esistenza di consuetudini applicabili16.

Anche solo con riferimento al diritto hindu, si può quindi osservare che, nonostante l'intento di semplificare, codificare e riformare, il diritto hindu ufficiale, applicato nelle corti indiane, non è del tutto uniforme. In realtà esistono molti diritti hindu ufficiali, senza contare i molti diritti hindu non ufficiali, che pur non applicati nelle corti rimangono importanti dal punto di vista della comprensione del diritto indiano ${ }^{17}$.

Il peso della difficoltà di funzionamento di questo sistema finisce quindi con il ricadere sulle corti. Essendo l'India una Repubblica secular, la religione dei giudici non è rilevante. Ciononostante, non è un dato banale che, ad esempio, un giudice hindu si trovi ad applicare regole di diritto islamico, e naturalmente si possono considerare tutte le combinazioni. Ancor più rilevante è il fatto che in alcuni casi, come abbiamo visto, i giudici dovranno applicare norme di diritto consuetudinario, non sempre di facile accertamento.

16 Si veda, ad esempio, Baby v. Jayant Mahadeo Jagtap and Ors, Bombay High Court, 1981. Viene considerato il caso di comunità dalit (Scheduled Castes) convertite al buddhismo che hanno adottato nuove forme di celebrazione del matrimonio. La Corte riconosce che queste nuove consuetudini per la celebrazione del matrimonio possono essere riconosciute dallo Stato, anche se si discostano da quelle generalmente riconosciute nel diritto hindu e anche se sono relativamente recenti. Sotto questo profilo si può anche rimarcare come la specificità di buddhisti, sikh e jainisti, a cui per espressa disposizione legislativa si applica il diritto hindu, possa essere riconosciuta almeno in parte grazie al rinvio alle consuetudini, non solo nel caso della forma di celebrazione del matrimonio.

$17 \mathrm{Si}$ veda, in generale, M. CHIBA (a cura di), Asian Indigenous Law in Interaction with Received Law, KPI, London-New York, 1986. 
Non si devono però trarre conseguenze troppo rapide da questa difficoltà. Se il valore della diversità in questo contesto è realmente importante, la difficoltà applicativa non è un argomento sufficiente a favore dell'uniformità. Tutto, o quasi, si può fare per proteggere un valore considerato importante, senza considerare che può apparire semplicistico assumere che con un Codice civile uniforme l'applicazione delle norme sarebbe realmente semplificata, nel momento in cui deve essere interpretata in contesti concreti in ogni caso caratterizzati da ampio pluralismo culturale.

Le questioni politiche hanno un grande peso in questo dibattito, ma non bisogna sottovalutare un aspetto più strettamente tecnico. Come si fa a scrivere un codice di questo tipo? Sappiamo che i codici sono preceduti e seguiti da una importante elaborazione dottrinale, che li prepara e poi li interpreta e attualizza. Un nuovo codice nasce da una crisi di funzionamento del sistema precedente. Se il Codice civile uniforme viene percepito come soluzione di un problema reale, indubbiamente altri problemi si pongono per la sua preparazione e altri ancora per la sua applicazione. In altri termini la qualità tecnica di questo codice potrebbe essere decisiva.

Esistono argomenti molto forti contro la stessa desiderabilità della promulgazione del Codice civile uniforme. Il principale è che i diritti personali nell'India di oggi sono applicati nel quadro costituzionale e sono in evoluzione. L'interazione dei diritti personali tra loro e con altre parti del diritto indiano, in particolare la Costituzione, unisce in un tutto questi diritti. Il non riconoscimento dei diritti personali, invece, corre il rischio di portare a una netta separazione tra un diritto ufficiale uniforme e diritti personali che resterebbero in parte comunque seguiti a livello non ufficiale e, a quel punto, senza la capacità di evoluzione che deriva loro dall'interazione costante con i valori costituzionali.

Siamo adesso, a mio parere, in una fase di "precipitazione". Questo meccanismo continuo di push and pull tra progetto di Codice civile uniforme e applicazione dei diritti personali richiede un passo ulteriore di organizzazione di questa complessità. Come detto in precedenza, la Law Commission ha ritenuto non necessario e in ogni prematuro un codice civile uniforme. Al tempo stesso si è espressa a favore di una codificazione ulteriore dei singoli diritti personali, come mezzo per promuovere il 
dibattito pubblico e favorire interventi socialmente importanti e lo sviluppo di una jurisprudence in materia di diritto di famiglia18.

Si potrà arrivare a un Codice civile uniforme, si potrà procedere con interventi legislativi sui singoli diritti personali, si potrà anche arrivare a una sorta di Indian Marriage Act, una legge uniforme secondo lo stile dell'Hindu Marriage Act, che conservi al suo interno un'apertura alla diversità. Quest'opzione avrebbe un forte valore simbolico nel tenere assieme tutti i diritti di famiglia personali in quanto "Indian", e sul piano tecnico permetterebbe una migliore integrazione con le norme di diritto territoriale di famiglia già esistenti e una elaborazione giurisprudenziale e dottrinale più coerente. Un punto di riferimento comune può forse aiutare sviluppi ulteriori del diritto di famiglia indiano e le stesse osservazioni potrebbero essere ripetute per il diritto delle successioni. In ogni caso, la complessità culturale, valoriale e sociale di questo diritto non può essere ridotta e tantomeno eliminata. Qualsiasi strada intraprenderà il sistema giuridico indiano si tratterà di un processo complesso, in questo caso nel significato positivo della potenziale originalità delle soluzioni che possono derivarne.

18 LAW COMMISSION OF INDIA, Consultation Paper on Reform of Family Law (31 August 2018), pp 17-18: "once codified, personal laws can be opened up for further public debates and scrutiny. Thus, history shows that amendments to codify personal laws is not only a tried and tested way of bringing targeted social legislation but also of developing jurisprudence on family laws". 